\title{
The origin of methane in the East Siberian Arctic Shelf unraveled with triple isotope analysis
}

\author{
Célia J. Sapart $^{1,2}$, Natalia Shakhova ${ }^{3,4}$, Igor Semiletov ${ }^{3,4,5}$, Joachim Jansen ${ }^{1,6}$, Sönke Szidat ${ }^{7}$, Denis Kosmach ${ }^{5}$, \\ Oleg Dudarev $^{5}$, Carina van der Veen ${ }^{1}$, Matthias Egger ${ }^{8}$, Valentine Sergienko ${ }^{9}$, Anatoly Salyuk ${ }^{5}$, Vladimir Tumskoy ${ }^{10}$, \\ Jean-Louis Tison ${ }^{2}$, and Thomas Röckmann ${ }^{1}$ \\ ${ }^{1}$ Institute for Marine and Atmospheric research Utrecht (IMAU), Utrecht University, Princetonplein 5, \\ 3584CC Utrecht, the Netherlands \\ ${ }^{2}$ Laboratoire de glaciologie, Universtié Libre de Bruxelles (ULB), Avenue Roosevelt 50, 1050 Brussels, Belgium \\ ${ }^{3}$ University Alaska Fairbanks, International Arctic Research Center, 930 Koyukuk Drive, Fairbanks, AK 99775, USA \\ ${ }^{4}$ Tomsk Polytechnic University, 30 Prospect Lenina, Tomsk, Russia \\ ${ }^{5}$ Russian Academy of Sciences, Far Eastern Branch, V.I. Il'ichov Pacific Ocenological Institute, 43 Baltiyskaya street, \\ Vladivostok 690041, Russia \\ ${ }^{6}$ Department of Geological Sciences and Bolin Centre for Climate Research, Stockholm University, \\ Svante Arrhenius väg 8, SE 114 18, Stockholm, Sweden \\ ${ }^{7}$ Department of Chemistry and Biochemistry \& Oeschger Centre for Climate Change Research, University of Bern, \\ Freiestrasse 3, 3012 Bern, Switzerland \\ ${ }^{8}$ Center for Geomicrobiology, Department of Bioscience, Aarhus University, Ny Munkegade 114, 8000 Aarhus, Denmark \\ ${ }^{9}$ Russian Academy of Sciences, Far Eastern Branch, Institute of Chemistry, 159 Prospect 100-letiya Vladivostoka, \\ Vladivostok 690022, Russia \\ ${ }^{10}$ Moscow State University, 1 Leninskie Gori, 119991, Moscow, Russia
}

Correspondence to: Célia J. Sapart (csapart@ulb.ac.be)

Received: 31 August 2016 - Discussion started: 7 September 2016

Revised: 30 January 2017 - Accepted: 9 March 2017 - Published: 5 May 2017

\begin{abstract}
The Arctic Ocean, especially the East Siberian Arctic Shelf (ESAS), has been proposed as a significant source of methane that might play an increasingly important role in the future. However, the underlying processes of formation, removal and transport associated with such emissions are to date strongly debated.

$\mathrm{CH}_{4}$ concentration and triple isotope composition were analyzed on gas extracted from sediment and water sampled at numerous locations on the shallow ESAS from 2007 to 2013. We find high concentrations (up to $500 \mu \mathrm{M}$ ) of $\mathrm{CH}_{4}$ in the pore water of the partially thawed subsea permafrost of this region. For all sediment cores, both hydrogen and carbon isotope data reveal the predominant occurrence of $\mathrm{CH}_{4}$ that is not of thermogenic origin as it has long been thought, but resultant from microbial $\mathrm{CH}_{4}$ formation. At some locations, meltwater from buried meteoric ice and/or old organic matter preserved in the subsea permafrost were used as sub-
\end{abstract}

strates. Radiocarbon data demonstrate that the $\mathrm{CH}_{4}$ present in the ESAS sediment is of Pleistocene age or older, but a small contribution of highly ${ }^{14} \mathrm{C}$-enriched $\mathrm{CH}_{4}$, from unknown origin, prohibits precise age determination for one sediment core and in the water column. Our sediment data suggest that at locations where bubble plumes have been observed, $\mathrm{CH}_{4}$ can escape anaerobic oxidation in the surface sediment.

\section{Introduction}

The Arctic subsea permafrost harbors a very large active carbon pool of similar size to the terrestrial Siberian permafrost reservoir (Shakhova et al., 2010a). Between 12 and $5 \mathrm{kyr}$ before present (BP), the Holocene transgression (Bauch et al., 2001) submerged extensive parts of the Pleistocene age 
terrestrial permafrost in northern Siberia, forming the very shallow East Siberian Arctic Shelf (ESAS; Romanovskii et al., 2005). As a result, the formerly terrestrial permafrost has been continuously exposed to increasing seawater temperature, salt and anoxic conditions (Dmitrenko et al., 2011; Nicolsky et al., 2012), allowing the remobilization of carbon from the Pleistocene reservoirs. The four suggested mechanisms controlling the release of Pleistocene carbon to the ESAS are the deepening of the permafrost level, gas hydrate degradation, coastal erosion and riverine discharge (e.g. Shakhova et al., 2005, 2009, 2010a, b, 2015; O'Connor et al., 2010; Winterfeld et al., 2015; James et al., 2016). Holoceneage carbon originating mainly from coastal erosion and riverine discharge (Charkin et al., 2011; Semiletov et al., 2012; Karlsson et al., 2011, 2016) has accumulated on the ESAS and overlays the Pleistocene age sediment (Vonk et al., 2012, 2014; Feng et al., 2013).

Under anaerobic conditions and depending on its type and quality (Schuur et al., 2013), the remobilized carbon can be used to produce $\mathrm{CH}_{4}$. Microbial $\mathrm{CH}_{4}$ is produced by methanogenesis using carbon dioxide $\left(\mathrm{CO}_{2}\right)$ or acetate as the main substrates according to the following reactions (Whiticar, 1999).

( $\mathrm{CO}_{2}$ reduction) $\mathrm{CO}_{2}+4 \mathrm{H}_{2} \rightarrow \mathrm{CH}_{4}+2 \mathrm{H}_{2} \mathrm{O}$

(Acetate fermentation) $\mathrm{CH}_{3} \mathrm{CO}_{2}^{-}+\mathrm{H}_{2} \mathrm{O} \rightarrow \mathrm{CH}_{4}+\mathrm{HCO}_{3}^{-}$

In the deep Earth layers, $\mathrm{CH}_{4}$ can also be formed through thermal degradation of organic matter (e.g. Schoell, 1988) and migrate towards the surface. This $\mathrm{CH}_{4}$ is considered thermogenic. A large part of the $\mathrm{CH}_{4}$ formed in the seafloor is removed by anaerobic oxidation with seawater sulfate in sediments (e.g. Reeburgh, 2007; Knittel and Boetius, 2009) or in the water column where $\mathrm{CH}_{4}$ can be consumed by aerobic methanotrophic bacteria under specific nutrient and redox conditions (e.g. Kessler et al., 2011; Mau et al., 2013; Steinle et al., 2015). Each type of $\mathrm{CH}_{4}$ formation and/or removal pathway produces $\mathrm{CH}_{4}$ with a characteristic isotopic signature $\left(\delta^{13} \mathrm{C}\right.$ and $\left.\delta \mathrm{D}\right)$ depending on the isotopic composition of the substrate and the kinetic isotope effect associated with the respective chemical reaction involved. Microorganisms need less energy to metabolize molecules with smaller bond energy, which leads to discrimination against heavy isotopes. Therefore, $\mathrm{CH}_{4}$ produced by methanogenesis has a lighter isotopic signature than its substrates, but when it is consumed, its remaining reservoir will become more enriched in heavy isotopes (e.g. Whiticar, 1999; Conrad, 2005). Diffusive transport can also cause isotopic discrimination, because lighter isotopologues diffuse faster than heavier ones. However, this fractionation is relatively small $(<5 \%$ : Fuex, 1980; <20\%o: Prinzhofer and Pernaton, 1997; and 3\%o: Chanton, 2005) compared to the isotopic fractionation associated with methanogenesis (7-95\% for $\delta^{13} \mathrm{C}$ and 260 $430 \%$ for $\delta \mathrm{D})$ and with $\mathrm{CH}_{4}$ oxidation $\left(2-39 \%\right.$ or $\delta^{13} \mathrm{C}$ and 66-350\% for $\delta \mathrm{D}$ ) (Whiticar, 1999; Holler et al., 2009).
Shakhova et al. (2010b) have shown that $\mathrm{CH}_{4}$ concentrations in the ESAS water were anomalously high (up to $500 \mathrm{nM}$ ) compared to $\mathrm{CH}_{4}$ values generally observed in ocean waters $(\sim 5 \mathrm{nM}$, Damm et al., 2008). Vigorous bubbling events ( 1.5 to 5.7 bubbles per second) were observed at some sites (Shakhova et al., 2013) as well as seepages of thermogenic $\mathrm{CH}_{4}$ (Cramer and Franke, 2005) indicating that part of the water column supersaturation likely results from a seabed source. The destabilization of gas hydrates is frequently discussed as a $\mathrm{CH}_{4}$ source in this region (e.g. Kvenvolden, 1988; Romanovskii et al., 2005; Shakhova et al., 2010a; Ruppel and Kessler, 2017); however, important gaps exist in the assessment of the quantity and the nature of the $\mathrm{CH}_{4}$ stored or formed in the Arctic seabed (e.g. Ruppel, 2014).

To disentangle the origin(s) of this $\mathrm{CH}_{4}$ anomaly, we measured $\mathrm{CH}_{4}$ concentration, stable isotope composition and (on selected samples) radiocarbon content in sediment and water samples from several winter campaigns and summer cruises from 2007 to 2013 on the ESAS and shelf edge. While stable isotope analyses help identify the chemical pathways involved in $\mathrm{CH}_{4}$ removal and formation processes, radiocarbon measurements give information on the age of the $\mathrm{CH}_{4}$ substrate. The combination of the isotope information thus helps in determining the possible origin(s) of this gas. Determining the stable isotope signatures of the main methane sources in the ESAS also remains crucial to better quantify the $\mathrm{CH}_{4}$ emissions in this region using isotopic- and back-trajectory analysis of atmospheric $\mathrm{CH}_{4}$ (Thornton et al., 2016).

\section{Method}

\subsection{Drilling and sediment sampling}

Summer surface sediment drilling and water sampling campaigns were carried out on research vessels, while the winter field campaigns were accomplished using an equipment caravan, which traveled over the sea ice to the drilling locations. In the latter case, casings were drilled through the fast ice into the seabed, allowing dry drilling using a rotary drill with $4 \mathrm{~m}$ casing with a newly built URB-4T drilling rig (made in 2011 by the Vorovskii Factory for Drilling Equipment, Ekaterinburg, Russia). Thawed and frozen sediments for each core were subsampled straight after (i.e. maximum a few minutes after) the drilling using ice screws for frozen samples and a heavy plastic syringe-like sampler for thawed samples at $20 \mathrm{~cm}$ vertical resolution.

\subsection{Gas extraction and measurement in sediments}

Sediment subsamples were subsequently immersed in glass vials filled with a saturated sodium chloride solution to drive gases out of solution, and capped with a septum for equilibration in an ultrasonic water bath at a temperature of $20^{\circ} \mathrm{C}$. The gas chromatograph (GC) used to measure $\mathrm{CH}_{4}$ concen- 
trations was equipped with two 10-Port gas sampling valves, a $2 \mathrm{~m}$ MolSieve $13 \mathrm{X}$ column, a $30 \mathrm{~m}$ capillary column and a 6 channel PeakSimple data system. A flame ionization detector (FID) was used for concentrations of $\mathrm{CH}_{4}<200 \mathrm{ppm}$ and a thermal conductivity detector (TCD) for concentrations of $\mathrm{CH}_{4}>200 \mathrm{ppm}$. The GC oven was operated isothermally at $40^{\circ} \mathrm{C}$ and the maximum detector temperature was held at $\approx 250^{\circ} \mathrm{C}$. The carrier gas used was helium. Daily calibration was performed with certified 1.96 and $99.999 \mathrm{ppm} \mathrm{CH}_{4}$ gas standards from Air Liquide, USA. The standard deviation of duplicate analyses (three to five replicates) was $<2 \%$. Reproducibility was $\sim 1 \%$ based on multiple standard injections during daily calibrations. The concentration of dissolved $\mathrm{CH}_{4}$ in the water and sediment samples was calculated with the Bunsen solubility coefficient for $\mathrm{CH}_{4}$ (Wiesenburg and Guinasso, 1979) for the appropriate equilibration temperature, pressure and the volume of headspace and water and/or sediment in each vial.

The stable isotope measurements were performed using a continuous-flow isotope ratio mass spectrometry (CF-IRMS) system as described in Brass and Röckmann (2010) and Sapart et al. (2011). Radiocarbon analyses could be performed only on the largest samples (containing more than $20 \mu \mathrm{g}$ of $\mathrm{CH}_{4}$ ). In that case, $\mathrm{CH}_{4}$ was preconcentrated and combusted to $\mathrm{CO}_{2}$. The ${ }^{14} \mathrm{C}$ content of the $\mathrm{CO}_{2}$ was measured by accelerator mass spectrometry (Szidat et al., 2014) using a specific gas inlet (Ruff et al., 2010).

\subsection{Gas extraction and measurement from seawater samples}

Water samples were collected directly from the Niskin bottles. Gas from seawater samples was extracted using a modified headspace vacuum-ultrasonic degassing method (Schmitt et al., 1991; Lammers and Suess, 1994). The gas released was accumulated in an evacuated burette to measure its quantity and was then transferred into a smaller flask for storage, and analyzed as described in Sect. 2.2.

\section{Results and discussion}

We present results of $\mathrm{CH}_{4}$ concentrations, stable isotope composition and (on selected samples) radiocarbon content on four shallow sediment cores $(<3 \mathrm{~m})$, four deep sediment cores (ID-11, IID-13, IIID-13, VD-13) (down to a maximum depth of $53 \mathrm{~m}$ in the Buor-Khaya Bay) and about fifty water samples from four coastal areas of the ESAS: the Lena Delta, the Buor-Khaya Bay, the Dmitry Laptev Strait and the shelf edge (Fig. 1) (see Table S1 for more detail on the sample locations). Because of the harsh field and weather conditions during this campaign, no sediment drilling was possible at the shelf edge; hence only water data are presented for this site. All water and sediment sampling, except for the ID-11 core, was performed at hotspot sites, i.e., at locations

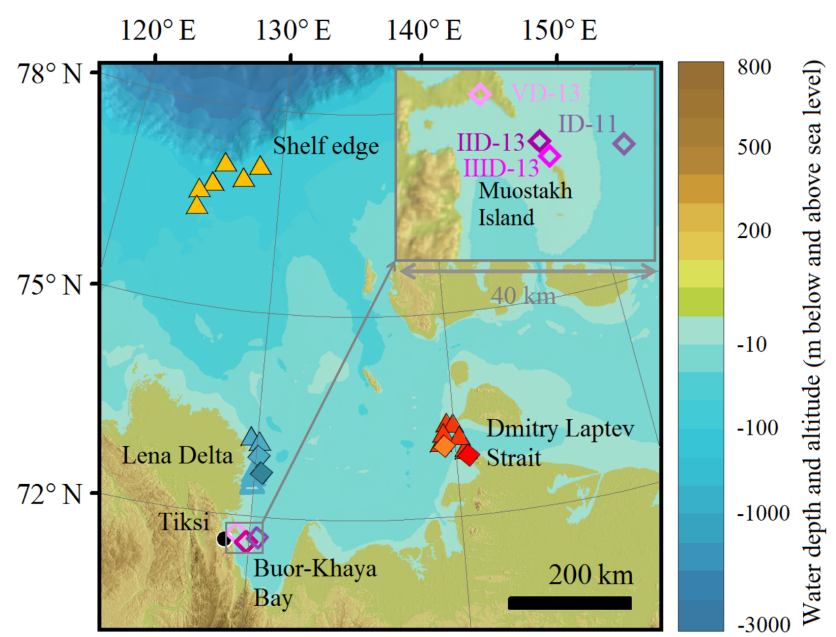

Figure 1. Sampling location. Water sampling (triangles), sediment drilling (diamonds). Summer sampling (close symbols) and winter sampling (open symbols). The color legends of the deep sediment cores are shown on the top right.

where active gas bubbling from the seafloor and high concentrations of dissolved $\mathrm{CH}_{4}$ were previously observed, as discussed in Shakhova et al. (2010a). The location of core ID11 is therefore referred to as the "non-ebullition site". This core, as well as the IIID-core, was thawed all the way down $(>50 \mathrm{~m})$ while the IID-13 and VD-13 cores were thawed down to 19 and $12 \mathrm{~m}$, respectively. Note that for the two latter cores, sampling was continued through the deeper frozen sediment to 30 and $35 \mathrm{~m}$ respectively. For more details on the lithology, the cryostructure and the sediment properties, see the Supplement, Sect. S1 and Figs. S1-S4.

\section{1 $\mathrm{CH}_{4}$ formation pathways in the sediment}

Depth profiles of $\mathrm{CH}_{4}$ concentration, stable isotope composition $\left({ }^{13} \mathrm{C}\right.$ and $\left.\delta \mathrm{D}\right)$ and the radiocarbon content (in percentage of modern carbon, pmC) are presented in Fig. 2. In both hotspot and non-ebullition cores, $\mathrm{CH}_{4}$ concentrations are far above values observed in the water column, and $\mathrm{CH}_{4}$ is strongly depleted in heavy stable isotopes in all sediment cores. $\mathrm{CH}_{4}$ in the hotspot cores IID-13, IIID-13 and VD-13 is more depleted in $\mathrm{D}$ and slightly more enriched in ${ }^{13} \mathrm{C}$ than in the non-ebullition core. These differences can be caused by the distance of the drill sites from the coast, the amount of time each site has been inundated and the differences in lithology (Supplement, Sect. S1). These factors will play a role in the substrate availability (Karlsson et al., 2011, 2016; Tesi et al., 2014, 2016). We will focus the discussion on the origin of the substrate(s) for each core below.

The expected stable isotope signatures of the three potential $\mathrm{CH}_{4}$ formation pathways in marine sediment (e.g. Whiticar, 1999), $\mathrm{CO}_{2}$ reduction, acetate fermentation and thermal degradation of organic matter, are depicted together 


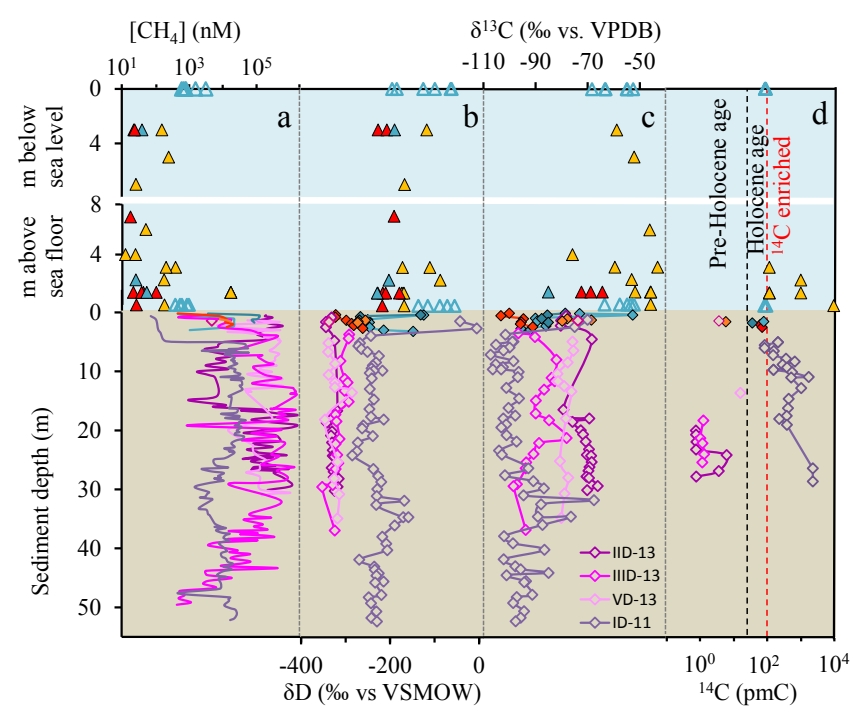

Figure 2. $\mathrm{CH}_{4}$ data from sediment and overlying water sampled on the East Siberian Arctic Shelf. Water sampling (triangles), sediment cores (diamonds). Summer sampling (close symbols) and winter sampling (open symbols). Buor-Khaya Bay (purple, ID-11: nonebullition site and IID-13, IIID-13 and VD13 hotspot sites), Dmitry Laptev Strait (red and orange), Lena Delta (light blue) and Shelf Edge (yellow) (see Fig. 1 for detailed location). (a) $\mathrm{CH}_{4}$ concentrations, (b) $\delta \mathrm{D}$ (\%o versus VSMOW), (c) $\delta^{13} \mathrm{C}$ (\%o versus VPDB), (d) ${ }^{14} \mathrm{C}$ (pmC). The red dotted line corresponds to modern values (i.e., $100 \mathrm{pmC}$ ) and the black dashed line corresponds to the onset of the Holocene (11000 years BP). Note that the $y$ axis for the water samples is divided in two sections. The upper part corresponds to the depth from the sea surface and the lower part corresponds to the depth from the seabed. See Figs. S1-S4 for the ice-bonded permafrost table depths and Table S1 for bathymetric information.

with our water and sediment stable isotope data in a dual isotope plot (Fig. 3). Overall, the deep sediment core data (diamonds) fall in between the isotope source signatures of the two main microbial $\mathrm{CH}_{4}$ formation pathways: carbonate reduction and acetate fermentation. These atypical stable isotope signatures could imply that $\mathrm{CH}_{4}$ is formed by a mixture of both microbial pathways and/or by using different substrates from the ones considered in Whiticar (1999). It is unlikely to be explained by physical alteration (e.g. diffusion, gravitational settling) because these processes would result in equal fractionation for the $\mathrm{CH}_{3} \mathrm{D}$ and ${ }^{13} \mathrm{CH}_{4}$ isotopologues.

For the non-ebullition core ID-11, most of the $\delta^{13} \mathrm{C}$ values are typical (though on the light end side) of the reduction of carbonates, but about $2 / 3$ of the samples show $\delta \mathrm{D}$ values that are considered too low (down to about $-60 \%$ ) for such a pathway. The most enriched $\delta \mathrm{D}$ data correspond to the top of this core and are discussed in Sect. 3.2. For this core, salinity measurements (from $20 \mathrm{PSU}$ at the surface to $13 \mathrm{PSU}$ at depth) indicate the presence of interstitial seawater all the way down the core. When the seawater sulfate enters the marine sediment, it provides sulfate-reducing bacteria with the

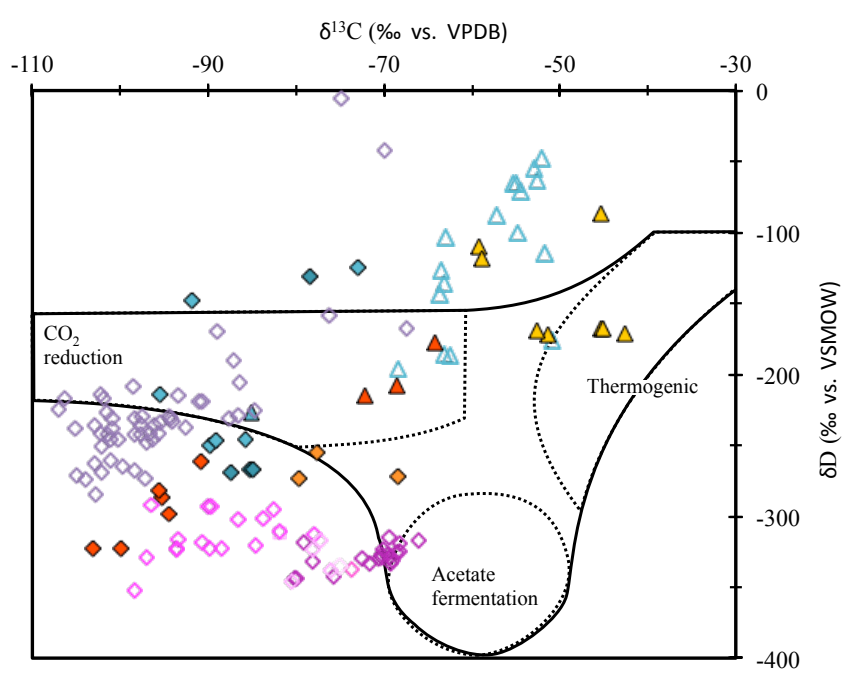

Figure 3. Dual-isotope $\mathrm{CH}_{4}$ plot. Legend is similar to Fig. 2. Areas delimited by black lines correspond to the three main $\mathrm{CH}_{4}$ formation processes and their isotopic signatures (Whiticar, 1999).

electron acceptor they need to out-compete methanogens for acetate (Lessner, 2009). This indicates that for this core, in situ (i.e. at the depth where the samples were taken) acetoclastic $\mathrm{CH}_{4}$ formation may be suppressed, despite an abundance of organic material. $\mathrm{CO}_{2}$ and water therefore remain the most likely non-competitive substrate for methanogens if $\mathrm{CH}_{4}$ formation would occur in the thawed permafrost. In that case, the very low $\delta \mathrm{D}$ values can be due to (1) a mixture of carbonate-reduced (formed in situ or not) and acetoclastic (migrating vertically or horizontally) $\mathrm{CH}_{4}$ or (2) the use of isotopically depleted hydrogen substrate for $\mathrm{CH}_{4}$ formation by carbonate reduction. On the dual isotope plot (Fig. 2), the area of the carbonate reduction pathway considers modern seawater as water substrate for carbonate reduction. However, the meltwater present in subsea permafrost originates from buried meteoric ice with much more depleted $\delta \mathrm{D}\left(\mathrm{H}_{2} \mathrm{O}\right)$ signatures. Chanton et al. (2006) and Brosius et al. (2012) reported values for $\delta \mathrm{D}\left(\mathrm{H}_{2} \mathrm{O}\right)$ of $-135 \pm 25 \%$ and $-220 \pm 30 \%$, respectively in old Arctic permafrost. This is about 200 to $105 \%$ more depleted in deuterium than modern Arctic seawater (Friedman et al., 1964). We suggest that methanogens present in the thawing permafrost (Koch et al., 2009) use and/or have used such depleted permafrost meltwater or unfrozen porewater as a hydrogen source to form $\mathrm{CH}_{4}$ with low $\delta \mathrm{D}$ values as it is observed in the non-ebullition core.

For the hotspot cores IID-13 IIID-13 and VD-13, the $\delta$ D values are characteristic of acetate fermentation, but the $\delta^{13} \mathrm{C}$ signatures are about $30 \%$ more depleted in ${ }^{13} \mathrm{C}$ in comparison to what has been measured previously from this pathway (e.g. Whiticar, 1999; Walter et al., 2008). This depletion in ${ }^{13} \mathrm{C}$ must originate from (1) the addition of carbonatereduced $\mathrm{CH}_{4}$ to an acetoclastic pool and/or (2) the recy- 

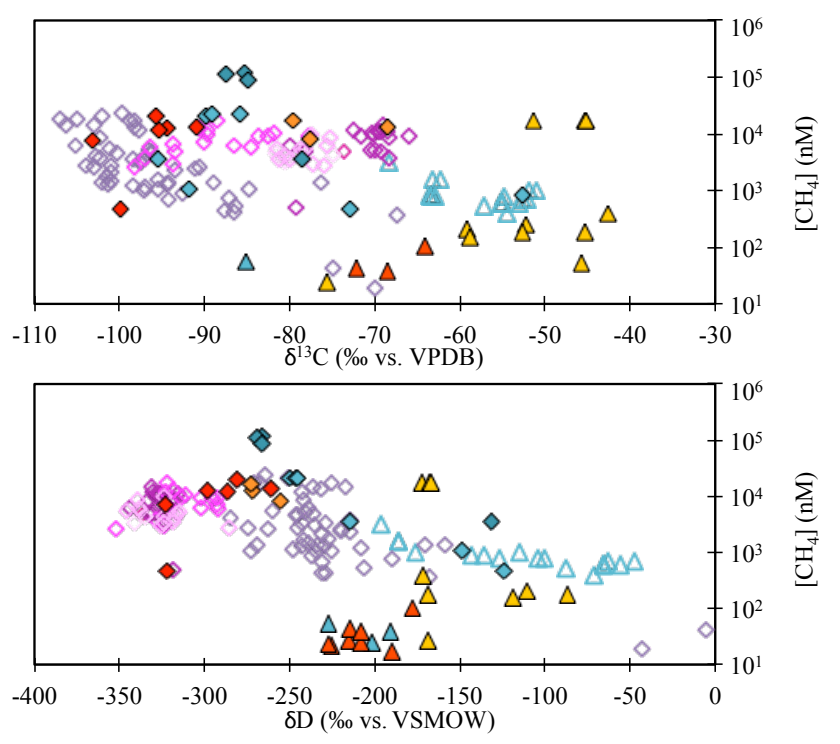

Figure 4. $\mathrm{CH}_{4}$ concentration versus stable isotope plots. Water sampling (triangles), sediment cores (diamonds). Summer sampling (close symbols) and winter sampling (open symbols). Buor-Khaya Bay (purple, ID-11: non-ebullition site and IID-13, IIID-13 and VD13 hotspot sites), Dmitry Laptev Strait (red and orange), Lena Delta (light blue) and Shelf Edge (yellow) (see Fig. 1 for detailed locations and Table S1 for bathymetric information).

cling of $\mathrm{CH}_{4}$ after AOM-mediated carbon isotope equilibrium under sulfate limitation conditions (Yoshinaga et al., 2014; Geprägs et al., 2016). For the latter, the ${ }^{13} \mathrm{C}$ depletion must be accompanied by a decrease in $\mathrm{CH}_{4}$ concentration, but this was not observed: the $\mathrm{CH}_{4}$ concentrations in our cores were relatively constant and not correlated with the $\delta^{13} \mathrm{C}$ values (Fig. 4). For these cores, because of the harsh conditions in the field, no reliable sulfate and salinity profiles could be retrieved, so unfortunately no sulfate data are available to support the interpretation.

The ${ }^{14} \mathrm{C}$ content of $\mathrm{CH}_{4}$ from the hotspot cores covers a range from 0.79 to $3.4 \mathrm{pmC}$ corresponding to a radiocarbon age of 26 to $39 \mathrm{kyr}$ BP (Fig. 2). This indicates a carbon substrate of Pleistocene age. For the ID-11 non-ebullition core, ${ }^{14} \mathrm{C}$ values are unexpectedly high and vary from $87 \mathrm{pmC}$ (radiocarbon age $=1 \mathrm{kyr} B P$ ) to $2367 \mathrm{pmC}$ (Fig. 2), which represents a substantial enrichment above the natural background. The same applies to water samples from the shelf edge. Note that levels close to $100 \mathrm{pmC}$ indicate modern values. Even samples that had been affected by the nuclear bomb testing in the 1950s and 1960s would show levels below $200 \mathrm{pmC}$; thus ${ }^{14} \mathrm{C}$ values $>200 \mathrm{pmC}$ cannot be caused by known natural processes. As discussed in the Supplement Sect. S2, local anthropogenic nuclear contribution, e.g. from nuclear waste buried in the coastal permafrost, is the most likely explanation for these elevated radiocarbon levels. The drilling location is shallow $(12.5 \mathrm{~m})$ and very difficult to reach and hence waste burial is very unlikely to have
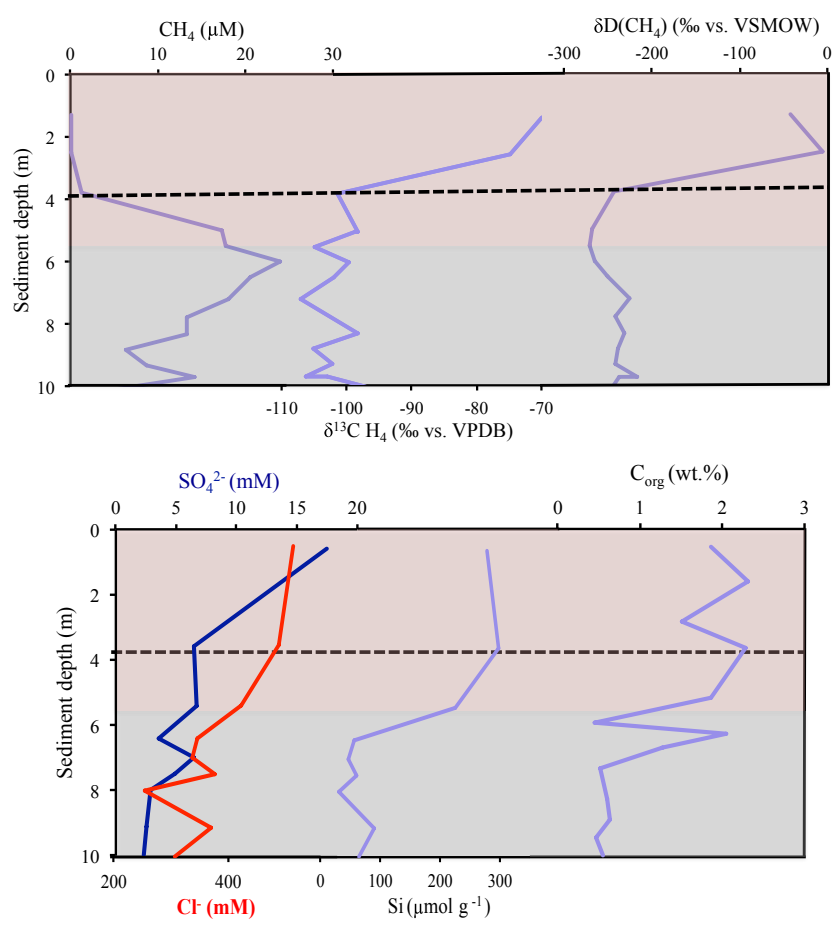

Figure 5. Close-up of the $\mathrm{CH}_{4}$ concentration, stable isotope and other biogeochemical data of the surface of the non-ebullition sediment core ID-11, from the Buor-Khaya Bay. Red shaded area corresponds to the marine sediment deposited during the Holocene transgression and the grey shaded area corresponds to the thawed permafrost layer. The black dotted line corresponds to the depth where $\mathrm{CH}_{4}$ oxidation starts to occur.

occurred directly in this area. Moreover, the highest contamination is observed at $30 \mathrm{~m}$ depth in the sediment, showing that it may not originate from the surface. Our first suggestion is that this anthropogenic contamination has been laterally transported in the pore water of the thawing subsea permafrost in the form of $\mathrm{CH}_{4}$ or of one of its precursors (e.g. dissolved inorganic carbon) from the coastal terrestrial permafrost to our drilling site (see Supplement Sect. S2 for more detailed). More data (e.g. of other radionuclides) would be essential to confirm this assumption.

The shallow sediment samples from hotspot sites have ${ }^{14} \mathrm{CH}_{4}$ values from 3 to $88 \mathrm{pmC}$ (radiocarbon age $=1$ $26 \mathrm{kyr} \mathrm{BP}$ ), showing the presence of old $\mathrm{CH}_{4}$ in surface sediment of relatively modern age and thus confirming the migration of old gas from deeper layers towards the surface. Note that the overall low content of organic carbon $(<2.3 \%)$ with a high fraction of lignin (Bröder et al., 2016; Vonk et al., 2014) in the surface sediment (Fig. 5), and the likely presence of sulfate, would severely inhibit $\mathrm{CH}_{4}$ formation in the marine layer; hence in situ methanogenesis there is highly unlikely.

We conclude that the $\mathrm{CH}_{4}$ present in the surface thawed subsea permafrost is formed mainly microbially. For the non- 
ebullition core, our observations imply that $\mathrm{CH}_{4}$ is at least partly not formed in situ in thawed subsea permafrost, but that it migrates vertically or laterally to the surface of the partially thawed ESAS subsea permafrost. For the hotspot cores, which are closer to the shore and more recently inundated (Table S1), most of the methane present is of acetoclastic origin and formed with Pleistocene carbon remobilized in the thawing subsea permafrost.

\section{2 $\mathrm{CH}_{4}$ removal pathways in the sediment}

The ID-11 non-ebullition site was the only coring location where no active bubbling was observed from the surface sediment. Here, the top $5.8 \mathrm{~m}$ consists of a thick silty-clay layer (Fig. S1) of marine origin as indicated by the higher salinity and silica concentrations (Fig. 5), typical of a marine environment enriched in diatoms. The increase in sulfate concentration, together with the strong $\mathrm{CH}_{4}$ concentration decrease and the isotopic enrichment in both ${ }^{13} \mathrm{C}$ and $\mathrm{D}$ towards the sediment surface, indicates that most of the $\mathrm{CH}_{4}$ diffusing through this thick Holocene marine layer is removed by anaerobic oxidation with sulfate in the surface sediment before reaching the water column.

This marine layer may also act as a physical barrier preventing gas migration towards the surface directly. The increase in $\mathrm{CH}_{4}$ concentration from 9 to $5.8 \mathrm{~m}$ depth without strong isotopic shifts (Fig. 5) and the acoustic data (Fig. 6) show that gas accumulates under this less permeable layer. Part of this gas might migrate laterally and be released to the water at locations where the marine clay layer is thinner or absent. The isotopic signatures of the $\mathrm{CH}_{4}$ in the pore water of the hotspot cores do not show isotopic fractionation toward the surface (Fig. 2). At these sites, ebullition processes may disturb the sulfate-reducing layer and advection may occur. This would reduce the amount of $\mathrm{CH}_{4}$ subject to anaerobic oxidation (only dissolved $\mathrm{CH}_{4}$ is accessible for methanotrophic organisms) and allow direct gas release to the water column.

Overduin et al. (2015) have reported $\mathrm{CH}_{4}$ concentration and $\delta^{13} \mathrm{C}$ values measured on one sediment core drilled in the Buor-Khaya Bay. The carbon isotopic signature of that core was typical of acetate fermentation in the frozen part of the core, but they observed a strong enrichment in ${ }^{13} \mathrm{C}$ associated with a decrease in $\mathrm{CH}_{4}$ concentration directly above the icebonded permafrost. They concluded that $\mathrm{CH}_{4}$ was strongly oxidized in the thawed subsea permafrost before reaching the water column. Our dataset suggests that the Overduin et al. core is not typical for the entire region as we did not observe similar enrichment in either $\mathrm{D}$ or ${ }^{13} \mathrm{C}$ associated with a decrease in $\mathrm{CH}_{4}$ concentration at the ice-bonded permafrost table for the partly frozen cores IID-13 and VD-13 (Figs. 2, S2 and S4).

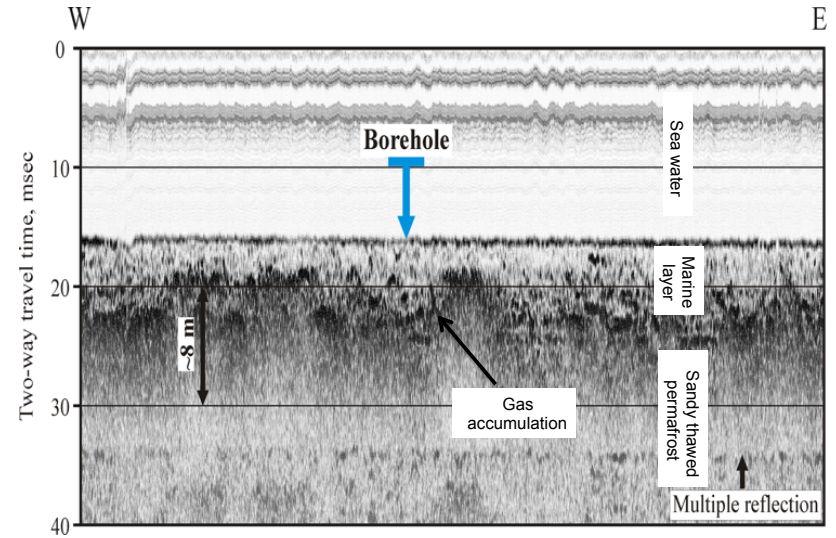

Figure 6. Acoustic profile of the borehole of the ID-11 drilling site. Darker areas represent changes in density between the different horizontal layers (Sergienko et al., 2012). We assume that these changes in density indicate gas accumulation, because the sediment at this location is totally thawed, so it is very unlikely to be ice.

\section{3 $\mathrm{CH}_{4}$ in the water}

Compared to the sediment samples, $\mathrm{CH}_{4}$ in the water samples is more enriched in heavy isotopes. The highest $\mathrm{CH}_{4}$ concentrations in the water column are observed close to the seabed and at the surface in the presence of sea ice (Fig. 2a blue triangles). The ${ }^{14} \mathrm{C}$ values of water samples are between 83 and $9560 \mathrm{pmC}$ (radiocarbon age $=2 \mathrm{kyr}$ BP to strongly enriched above natural present-day values) (Fig. 2d) (Supplement Sect. S2). For the water samples we only encountered the highly enriched ${ }^{14} \mathrm{CH}_{4}$ values at the shelf edge. As demonstrated by the ${ }^{14} \mathrm{CH}_{4}$ data in the non-ebullition core ID-11, this anomaly likely originates from anthropogenic contamination in the sediment. Hence, we suggest that this signature may be diluted over the shelf but becomes indiscernible at locations where a strong release of old $\mathrm{CH}_{4}$ from the sediment occurs. This could explain the broad range of $\mathrm{pmC}$ values observed in the water column.

Several scenarios may explain the difference in stable isotope signatures between the water samples and sediment samples. The first assumes a mixture of microbial $\mathrm{CH}_{4}$ with a source that is more enriched in heavy isotopes. This source could be either a water source or thermal degradation of organic matter in the Earth's deep crust. In the marine environment, $\mathrm{CH}_{4}$ could in principle be produced at the pycnocline, where natural differences of water density create a "fluid bottom", on which organic particles and pellets could accumulate as substrate for in situ methanogenesis (Damm et al., 2008; Karl et al., 2008; Sasakawa et al., 2008). In the ESAS, the pycnocline is very shallow, and at the location of sampling, low primary production is expected because of darkness and ice cover in the winter and because of the little available sunlight in the summer due to the high solar zenith angles and the very turbid waters (Semiletov et al., 
2016). Bussmann (2013) has investigated the distribution of $\mathrm{CH}_{4}$ in the estuary of the Lena, one of the largest Russian rivers draining into the ESAS. They reported high $\mathrm{CH}_{4}$ concentrations (up to $1500 \mathrm{nM}$ ) in the river and in the creeks draining from permafrost soil and a strong decrease in the Buor-Khaya Bay (down to $26-33 \mathrm{nM}$ ). They concluded that the $\mathrm{CH}_{4}$ contained in the rich waters of the river was, for the most part, not reaching the marine waters, but that it was released by diffusion into the atmosphere before reaching the bay. A large water source is therefore unlikely to explain the $\mathrm{CH}_{4}$ saturation we observe in the ESAS coastal waters.

Thermogenic emissions from the sediment are possible, especially from the fault zone near the shelf edge where we find strong heavy isotope enrichment in the water. While we have not measured any $\mathrm{CH}_{4}$ with a thermogenic stable isotopic signature in our deep sediment cores from the continental shelf, it could be present in the sediments of the shelf edge (which we were unable to sample due to rough field conditions). Moreover, no measurements could be performed directly on gas bubbles (because of the low probability of trapping bubbles in the Niskin bottles during sampling), which at the shelf edge might partly originate from thermal degradation of organic matter.

The difference between the water and sediment samples may also result from substantial oxidation of the $\mathrm{CH}_{4}$ emitted from the deep sediment. Such a process should involve enrichments in $\mathrm{D}$ and ${ }^{13} \mathrm{C}$ associated with a decrease in $\mathrm{CH}_{4}$ concentration. This pattern is only observed for the winter water samples of the Lena Delta (Fig. 4, blue open triangles) where $\mathrm{CH}_{4}$ trapped under the sea ice could be removed by aerobic oxidation. All other water data were collected in the summer and do not show any clear isotopic enrichment correlated with concentration decrease. This could be explained by the continuous addition of $\mathrm{CH}_{4}$ from the sediment and its direct diffusion from the water into the atmosphere in the summer, especially during storms (Shakhova et al., 2013). These processes as well as water-column mixing could mask any oxidative isotope signature.

In the winter, $\mathrm{CH}_{4}$ likely accumulates under the sea ice where the bubble and dissolved phases could equilibrate and aerobic oxidation could occur, while in the summer the gas bubbles will directly reach the atmosphere. In the sediment, gas bubbles have time to equilibrate with pore water, especially when the gas is trapped under relatively impermeable sediment, e.g. the Holocene marine silty-clay layer. Therefore, we assume that in the sediment, the pore water can be in equilibrium with the gas bubbles, while we suggest that in the summer the seawater bubbles may travel too rapidly to reach an isotopic equilibrium with the dissolved gas and to be oxidized. This means that the $\mathrm{CH}_{4}$ isotopic signature of the gas bubbles may not strongly affect the $\mathrm{CH}_{4}$ dissolved in seawater, which could also explain the difference observed between the water and sediment stable isotopes values.

\section{Conclusion}

Our triple isotope dataset of $\mathrm{CH}_{4}$ from the sediment and water of the shallow ESAS reveals the presence of $\mathrm{CH}_{4}$ of microbial origin formed on old carbon with unexpectedly low stable carbon $\left(\delta^{13} \mathrm{C}\right.$ as low as $\left.-108 \%\right)$ and hydrogen $(\delta \mathrm{D}$ as low as $-350 \%$ ) isotope signatures down to about $50 \mathrm{~m}$ under the seabed in the thawed permafrost. These data demonstrate that at locations where a thick marine clay layer is present, this $\mathrm{CH}_{4}$ is partially oxidized before reaching the seawater. However, at locations where ebullition was observed from the seabed, no oxidation was identified in the stable isotope surface sediment profile. In that case, and considering the very shallow water column $(<10 \mathrm{~m})$ in this area, this microbial gas will likely reach the atmosphere when sea ice is absent. Our results show that thawing subsea permafrost of the ESAS emits $\mathrm{CH}_{4}$ with an isotopic signature that cannot be easily distinguished from Arctic wetland emissions when looking only at stable isotope data. This similarity might complicate recent efforts to quantify Arctic $\mathrm{CH}_{4}$ source strengths on the basis of isotopic- and back-trajectory analysis of atmospheric $\mathrm{CH}_{4}$. Further in situ work is necessary - specifically on the isotopic composition of $\mathrm{CH}_{4}$ in gas bubbles that reach the atmosphere - to better quantify the contribution of the ESAS to the global methane budget.

Data availability. The data presented in this paper are available at https://www.projects.science.uu.nl/atmosphereclimate/Data.php.

\section{The Supplement related to this article is available online at doi:10.5194/bg-14-2283-2017-supplement.}

Author contributions. Célia J. Sapart, Natalia Shakhova, Thomas Röckmann, Joachim Jansen, Sönke Szidat, Igor Semiletov, Jean-Louis Tison and Matthias Egger worked on the scientific interpretation and wrote the manuscript. Natalia Shakhova and Igor Semiletov planned the research and organized the multiyear fieldwork campaigns. Carina van der Veen, Célia J. Sapart, Sönke Szidat and Joachim Jansen performed the isotopic analyses. Igor Semiletov, Denis Kosmach, Oleg Dudarev, Valentine Sergienko, Anatoly Salyuk and Vladimir Tumskoy performed the water sampling, sediment drilling, headspace preparation and $\mathrm{CH}_{4}$ concentration measurements on the field.

Competing interests. The authors declare that they have no conflict of interest.

Acknowledgements. We are grateful for the help of Gary Salazar (University of Bern) with the ${ }^{14} \mathrm{C}$ measurements. This research was supported by the Russian Government (no. 14.Z50.31.0012/03.19.2014), the US National Science Foundation (OPP ARC-1023281; 0909546) and the NOAA 
Climate Program office (NA08OAR4600758). Natalia Shakhova, Denis Kosmach and Oleg Dudarev acknowledge support from the Russian Science Foundation (no. 15-17-20032).

We would like to thank Jorien Vonk, Alain Prinzhofer, Helge Niemann, Nadine Mattielli and Dominique Weiss for the fruitful discussions and precious help in the interpretation of these data and Rebecca Fisher, Elise van Winden and Joralf Quist for their help with the stable isotope measurements and system calibration.

Edited by: F. Peterse

Reviewed by: B. F. Thornton and two anonymous referees

\section{References}

Bauch, H. A., Mueller-Lupp, T., Taldenkova, E., Spielhagen, R. F., Kassens, H., Grootes, P. M., Thiede, J., Heinemeier, J., and Petryashov, V. V.: Chronology of the Holocene transgression at the North Siberian margin, Global Planet. Change, 31, 125-139, 2001.

Brass, M. and Röckmann, T.: Continuous-flow isotope ratio mass spectrometry method for carbon and hydrogen isotope measurements on atmospheric methane, Atmos. Meas. Tech., 3, 17071721, doi:10.5194/amt-3-1707-2010, 2010.

Bröder, L., Tesi, T., Andersson, A., Eglinton T. I., Semiletov, I. P., Dudarev, O. V., Roos, P., and Gustafsson, Ö.: Historical records of organic matter supply and degradation status in the East Siberian Sea, Org. Geochem., 91, 16-30, 2016.

Brosius, L. S., Walter Anthony, K. M., Grosse, G., Chanton, J. P., Farquharson, L. M., Overduin, P. P., and Meyer, H.: Using the deuterium isotope composition of permafrost meltwater to constrain thermokarst lake contributions to atmospheric $\mathrm{CH}_{4}$ during the last deglaciation, J. Geophys. Res., 117, G01022, doi:10.1029/2011JG001810, 2012.

Bussmann, I.: Distribution of methane in the Lena Delta and Buor-Khaya Bay, Russia, Biogeosciences, 10, 4641-4652, doi:10.5194/bg-10-4641-2013, 2013.

Chanton, J. P.: The effect of gas transport on the isotope signature of methane in wetlands, Org. Geochem., 36, 753-768. 2005.

Chanton, J. P., Fields, D., and Hines, M. E.: Controls on the hydrogen isotopic composition of biogenic methane from highlatitude terrestrial wetlands, J. Geophys. Res., 111, G04004, doi:10.1029/2005JG000134, 2006.

Charkin, A. N., Dudarev, O. V., Semiletov, I. P., Kruhmalev, A. V., Vonk, J. E., Sánchez-García, L., Karlsson, E., and Gustafsson, Ö.: Seasonal and interannual variability of sedimentation and organic matter distribution in the Buor-Khaya Gulf: the primary recipient of input from Lena River and coastal erosion in the southeast Laptev Sea, Biogeosciences, 8, 2581-2594, doi:10.5194/bg8-2581-2011, 2011.

Conrad, R.: Quantification of methanogenic pathways using stable isotopic signatures: a review and a proposal, Org. Geochem., 36, 739-752, 2005.

Cramer, B. and Franke, D.: Indications for an active petroleum system in the Laptev Sea, NE Siberia, J. Petr. Geology, 28, 369-384, 2005.

Damm, E., Kiene, R. P., Schwarz, J., Falck, E., and Dieckmann, G.: Methane cycling in Arctic shelf water and its relationship with phytoplankton biomass and DMSP, Mar. Chem., 19, 45-59, 2008.

Dmitrenko, I. A., Kirillov, S. A., Tremblay, L. B., Kassens, H., Ansimov, O. A., Lavrov, S. A., Razumov, S. O., and Grigoriev, M. N.: Recent changes in shelf hydrography in the Siberian Arctic: Potential for subsea permafrost instability, J. Geophys. Res., 116, C10027, doi:10.1029/2011JC007218, 2011.

Feng, X., Vonk, J. E., van Dongen, B. E., Gustafsson, Ö., Semiletov, I. P., Dudarev, O. V., Wang, Z., Montluçon, D. B., Wacker, L., and Eglinton, T. I.: Differential mobilization of terrestrial carbon pools in Eurasion Arctic river basins, P. Natl. Acad. Sci. USA, 110, 14168-14173, 2013.

Friedman, I., Redfield, A. C., Schoen, B., and Harris, J.: The Variation of the Deuterium Content of Natural Waters in the Hydrologic Cycle, Rev. Geophys., 2, 177-224, 1964.

Fuex, A. N.: Experimental evidence against an appreciable isotopic fractionation of methane during migration, in: Douglas, A. G. and Maxwell, J. R., Advances in Organic Get-chemistry, Pergamon, Oxford, 1980.

Geprägs, P., Torres, M. E., Mau, S., Kasten, S., Römer, M., and Bohrmann, G.: Carbon cycling fed by methane seepage at the shallow Cumberland Bay, South Georgia, sub-Antarctic, Geochem. Geophy. Geosy., 17, 1401-1418, 2016.

Holler, T., Wegener, G., Knittel, K., Boetius, A., Brunner, B., Kuypers, M. M. M., and Widdel, F.: Substantial ${ }^{13} \mathrm{C} /{ }^{12} \mathrm{C}$ and $\mathrm{D} / \mathrm{H}$ fractionation during anaerobic oxidation of methane by marine consortia enriched in vitro, Environ. Microbiol. Rep., 1, 370-376, 2009.

James, R. H., Bousquet, P., Bussmann, I., Haeckel, M., Kipfer, R., Leifer, I., Niemann, H., Ostrovsky, I., Piskozub, J., Rehder, G., Treude, T., Vielstädte, L., and Greinert, J.: Effects of climate change on methane emissions from seafloor sediments in the Arctic Ocean: A review, Limnol. Oceanogr., 61, 283-299, 2016.

Karl, D. M., Beversdorf, L., Bjorkman, K. M., Church, M. J., Martinez, A., and Delong, E. F.: Aerobic production of methane in the sea, Nat. Geosci., 1, 473-478, 2008.

Karlsson, E., Gelting, J., Tesi, T., van Dongen, B., Andersson, A., Semiletov, I., Charkin, A., Dudarev, O., and Gustafsson, Ö.: Different sources and degradation state of dissolved, particulate, and sedimentary organic matter along the Eurasian Arctic coastal margin, Global Biogeochem. Cy., 30, 898-919, 2016.

Karlsson, E. S., Charkin, A., Dudarev, O., Semiletov, I., Vonk, J. E., Sánchez-García, L., Andersson, A., and Gustafsson, Ö.: Carbon isotopes and lipid biomarker investigation of sources, transport and degradation of terrestrial organic matter in the Buor-Khaya Bay, SE Laptev Sea, Biogeosciences, 8, 1865-1879, doi:10.5194/bg-8-1865-2011, 2011.

Kessler, J. D., Valentine, D. L., Redmond, M. C., Du, M., Chan, E. W., Mendes, S. D., Quiroz, E. W., Villanueva, C. J., Shusta, S. S., Werra, L. M., Yvon-Lewis, S. A., and Weber, T. C.: A persistent oxygen anomaly reveals the fate of spilled methane in the deep Gulf of Mexico, Science, 331, 312-315, 2011.

Knittel, K. and Boetius, A.: Anaerobic oxidation of methane: Progress with an unknown process, Annu. Rev. Microbiol., 63, 311-334, 2009.

Koch, K., Knoblauch, C., and Wagner, D.: Methanogenic community composition and anaerobic carbon turnover in submarine permafrost sediments of the Siberian Laptev Sea, Environ. Microbiol., 11, 657-668, 2009. 
Kvenvolden, K. A.: Methane hydrates and global climate, Global Biogeochem. Cy., 2, 221-229, 1988.

Lammers, S. and Suess, E.: An improved head-space analysis method for methane in seawater, Mar. Chem., 47, 115-125, 1994.

Lessner, D. J.: Methanogenesis Biochemistry, in: Encyclopedia of Life Sciences (ELS), Wiley and Sons Ltd, Chichester, UK, 2009.

Mau, S., Blees, J., Helmke, E., Niemann, H., and Damm, E.: Vertical distribution of methane oxidation and methanotrophic response to elevated methane concentrations in stratified waters of the Arctic fjord Storfjorden (Svalbard, Norway), Biogeosciences, 10, 6267-6278, doi:10.5194/bg-10-6267-2013, 2013

Nicolsky, D., Romanovsky, V. E., Romanovskii, N. N., Kholodov, A. L., Shakhova, N. E., and Semiletov, I. P.: Modeling sub-sea permafrost in the East Siberian Arctic Shelf: The Laptev Sea region, J. Geophys. Res., 117, F03028, doi:10.1029/2012JF002358, 2012.

O’Connor, F. M., Boucher, O., Gedney, N., Jones, C. D., Folberth, G. A., Coppell, R., Friedlingstein, P., Collins, W. J., Chappellaz, J., Ridley, J., and Johnson, C. E.: Possible role of wetlands, permafrost, and methane hydrates in the methane cycle under future climate change: A review, Rev. Geophys., 48, RG4005, doi:10.1029/2010RG000326, 2010.

Overduin, P. P., Liebner, S., Knoblauch, C., Günther, F., Wetterich, S., Schirrmeister, L., Hubberten, H.-W., and Grigoriev, M. N.: Methane oxidation following submarine permafrost degradation: Measurements from a central Laptev Sea shelf borehole, J. Geophys. Res.-Biogeo., 120, 965-978, doi:10.1002/2014JG002862, 2015.

Prinzhofer, A. and Pernaton, E.: Isotopically light methane in natural gas: bacterial imprint or diffusive fractionation?, Chem. Geol., 142, 193-200, 1997.

Reeburgh, W. S.: Oceanic methane biogeochemistry, Chem. Rev., 107, 486-513, 2007.

Romanovskii, N. N., Hubberten, H.-W., Gavrilov, A. V., Eliseeva, A. A., and Tipenko, G. S.: Offshore permafrost and gas hydrate stability zone on the shelf of East Siberian Seas, Geo-Mar. Lett., 25, 167-182, 2005.

Ruff, M., Szidat, S., Gäggeler, H. W., Suter, M., Synal, H.-A., and Wacker, L.: Gaseous radiocarbon measurements of small samples, Nucl. Instrum. Meth. B, 268, 790-794, 2010.

Ruppel, C.: Permafrost-associated gas hydrate: Is it really approximately $1 \%$ of the global system?, J. Chem. Eng. Data, 60, 429436, 2014

Ruppel, C. D. and Kessler, J. D.: The interaction of climate change and methane hydrates, Rev. Geophys., doi:10.1002/2016RG000534, online first, 2017.

Sapart, C. J., van der Veen, C., Vigano, I., Brass,, M., van de Wal, R. S. W., Bock, M., Fischer, H., Sowers, T., Buizert, C., Sperlich, P., Blunier, T., Behrens, M., Schmitt, J., Seth, B., and Röckmann, T.: Simultaneous stable isotope analysis of methane and nitrous oxide on ice core samples, Atmos. Meas. Tech., 4, 2607-2618, doi:10.5194/amt-4-2607-2011, 2011.

Sasakawa, M., Tsunogai, U., Kameyama,S., Nakagawa, F., Nojiri, Y., and Tsuda, A.: Carbon isotopic characterization for the origin of excess methane in subsurface seawater, J. Geophys. Res., 113, 7539-7545, doi:10.1016/j.atmosenv.2006.07.014, 2008.

Schmitt, M., Faber, E., Botz, R., and Stoffers, P.: Extraction of methane from seawater using ultrasonic vacuum degassing, Anal. Chem., 63, 529-532, 1991.
Schoell, M.: Multiple origins of methane on Earth, Chem. Geol., 71, 1-10, 1988.

Schuur, E. A. G., Abbott, B. W., Bowden, W. B., Brovkin, V., Camill, P., Canadell, J. G., Chanton, J. P., Chapin, F. S., Christensen, T. R., Ciais, P., Crosby, B. T., Czimczik, C. I., Grosse, G., Harden, J., Hayes, D. J., Hugelius, G., Jastrow, J. D., Jones, J. B., Kleinen, T., Koven, C. D., Krinner, G., Kuhry, P., Lawrence, D. M., McGuire, A. D., Natali, S. M., O’Donnell, J. A., Ping, C. L., Riley, W. J., Rinke, A., Romanovsky, V. E., Sannel, A. B. K., Schädel, C., Schaefer, K., Sky, J., Subin, Z. M., Tarnocai, C., Turetsky, M. R., Waldrop, M. P., Walter Anthony, K. M., Wickland, K. P., Wilson, C. J., and Zimov, S. A.: Expert assessment of vulnerability of permafrost carbon to climate change, Climatic Change, 119, 359-374, 2013.

Semiletov, I. P., Shakhova, N. E., Sergienko, V. I., Pipko, I. I., and Dudarev, O.: On Carbon Transport and Fate in the East Siberian Arctic Land-Shelf-Atmosphere System, Environ. Res. Lett., 7, 15201, doi:10.1088/1748-9326/7/1/015201, 2012.

Semiletov, I., Pipko, I., Gustafsson, Ö., Anderson, L. G., Sergienko, V., Pugach, S., Dudarev, O., Charkin, A., Gukov, A., Bröder, L., Andersson, A., Spivak, E., and Shakhova, N.: Acidification of East Siberian Arctic Shelf water through addition of freshwater and terrestrial carbon, Nat. Geosci., 9, 361-365, 2016.

Sergienko, V. I., Lobkovskii, L. I., Semiletov, I. P., Dudarev, O. V., Dmitrievskii, N. N., Shakhova, N. E., Romanovskii, N. N., Kosmach, D. A., Nikol'skii, D. N., Nikiforov, S. L., Salomatin, A. S., Anan'ev, R. A., Roslyakov, A. G., Salyuk, A. N., Karnaukh, V. V., Chernykh, D. B., Tumskoi, V. E., Yusupov, V. I., Kurilenko, A. V., Chuvilin, E. M., and Bukhanov, B. A.: The Degradation of Submarine Permafrost and the Destruction of Hydrates on the Shelf of East Arctic Seas as a Potential Cause of the "Methane Catastrophe": Some Results of Integrated Studies in 2011, Dokl. Earth Sci., 446, 1132-1137, 2012.

Shakhova, N., Semiletov, I., and Panteleev, G.: The distribution of methane on the Siberian Arctic shelves: Implications for the marine methane cycle, Geophys. Res. Lett., 32, L09601, doi:10.1029/2005GL022751, 2005.

Shakhova, N., Semiletov, I., Leifer, I., Rekant, P., Salyuk, A., and Kosmach, D.: Geochemical and geophysical evidence of methane release from the inner East Siberian Shelf, J. Geophys. Res., 115, C08007, doi:10.1029/2009JC005602, 2010a.

Shakhova, N., Semiletov, I., Salyuk, A., Yusupov, V., Kosmach, D., and Gustafsson, O.: Extensive methane venting to the atmosphere from sediments of the East Siberian Arctic Shelf, Science, 327, 1246-1250, $2010 b$.

Shakhova, N., Semiletov, I., Leifer, I., Sergienko, V., Salyuk, A., Kosmach, D., Chernikh, D., Stubbs, Ch., Nicolsky, D., Tumskoy, V., and Gustafsson, O.: Ebullition and storm-induced methane release from the East Siberian Arctic Shelf, Nat. Geosci., 7, 64 70, 2013.

Shakhova, N., Semiletov, I., Sergienko, V., Lobkovsky, L., Yusupov, V., Salyuk, A., Salomatin, A., Chernykh, D., Kosmach, D., Panteleev, G., Nicolsky, D., Samarkin, V., Joye, S., Charkin, A., Dudarev, O., Meluzov, A., and Gustafsson, O.: The East Siberian Arctic Shelf: towards further assessment of permafrost-related methane fluxes and role of sea ice, Philos. T. R. Soc. A, 373, 20140451, doi:10.1098/rsta.2014.0451, 2015.

Shakhova, N. E., Nicolsky, D., and Semiletov, I. P.: On the current state of sub-sea permafrost in the East-Siberian Shelf testing of 
modeling results by observational data, Transactions of Russian Academy of Sciences, Vol. 429, 2009 (translated in English by Springer).

Steinle, L., Graves, C., Treude, T., Ferré, B., Biastoch, A., Bussmann, I., Berndt, C., Krastel, S., James, R. H., Behrens, E., Böning, C. W., Greinert, J., Sapart, C. J., Scheinert, M., Sommer, S., Lehmann, M. F., and Niemann, H.: Water column methanotrophy controller by a rapod oceanographic switch, Nat. Geosci., 8, 378-382, 2015.

Szidat, S., Salazar, G. A., Vogel, E., Battaglia, M., Wacker, L., Synal, H.-A., and Türler, A.: ${ }^{14} \mathrm{C}$ analysis and sample preparation at the new Bern Laboratory for the Analysis of Radiocarbon with AMS (LARA), Radiocarbon, 56, 561-566, 2014.

Tesi, T., Semiletov, I., Hugelius, G., Dudarev, O., Kuhry, P., and Gustafsson, Ö.: Composition and fate of terrigenous organic matter along the Arctic land-ocean continuum in East Siberia: Insights from biomarkers and carbon isotopes, Geochim. Cosmochim. Ac., 133, 235-256, 2014.

Tesi, T., Semiletov, I., Dudarev, O., Andersson, A., and Gustafsson, Ö.: Matrix association effects on hydrodynamic sorting and degradation of terrestrial organic matter during cross-shelf transport in the Laptev and East Siberian shelf seas, J. Geophys. Res.Biogeo., 121, 731-752, doi:10.1002/2015JG003067, 2016.

Thornton, B. F., Wik, M., and Crill, P. M.: Double-counting challenges the accuracy of high-latitude methane inventories, Geophys. Res. Lett., 43, 12569-12577, 2016.

Vonk, J. E., Sánchez-García, L., van Dongen, B. E., Alling, V., Kosmach, D., Charkin, A., Semiletov, I. P., Dudarev, O. V., Shakhova, N., Roos, P., Eglinton, T. I., Andersson, A., and Gustafsson, Ö.: Activation of old carbon by erosion of coastal and subsea permafrost in Arctic Siberia, Nature, 489, 137-140, 2012 .
Vonk, J. E., Semiletov, I. P., Dudarev, O. V., Eglinton, T. I., Andersson, A., Shakhova, N., Charkin, A., Heim, B., and Gustafsson, Ö.: Preferential burial of permafrost derived organic carbon in Siberian-Arctic shelf waters, J. Geophys. Res., 119, 8410-8421, 2014.

Walter, K. M., Chanton, J. P., Chapin III, F. S., Schuur, E. A. G., and Zimov, S. A.: Methane production and bubble emissions from arctic lakes: Isotopic implications for source pathways and ages, J. Geophys. Res., 113, 305-315, 2008.

Whiticar, M. J.: Carbon and hydrogen isotope systematics of bacterial formation and oxidation of methane, Chem. Geo., 161, 291314, 1999.

Wiesenburg, D. A. and Guinasso Jr., N. L.: Equilibrium solubilities of methane, carbon monoxide and hydrogen in salt and sea water, J. Chem. Eng. Data, 24, 356-360, 1979.

Winterfeld, M., Laepple, T., and Mollenhauer, G.: Characterization of particulate organic matter in the Lena River delta and adjacent nearshore zone, NE Siberia - Part I: Radiocarbon inventories, Biogeosciences, 12, 3769-3788, doi:10.5194/bg-12-3769-2015, 2015.

Yoshinaga, M. Y., Holler, T., Goldhammer, T., Wegener, G., Pohlman, J. W., Brunner, B., Kuypers, M. M. M., Hinrichs, K., and Elvert, M.: Carbon isotope equilibration during sulphatelimited anaerobic oxidation of methane, Nat. Geosci., 7, 190194, 2014. 